\title{
Modeling the profitability of commercial banks in Indonesia*
}

\author{
Tri Wulandari ${ }^{1, \text { a }}$, Lukytawati Anggraeni ${ }^{2}$, Trias Andati ${ }^{3}$ \\ 1,2,3 Management and Business Graduate Program, Bogor Agriculture Institute, Bogor, Indonesia. \\ a Otoritas Jasa Keuangan office, Jakarta, Indonesia. \\ E-mail: trulandari117@gmail.com
}

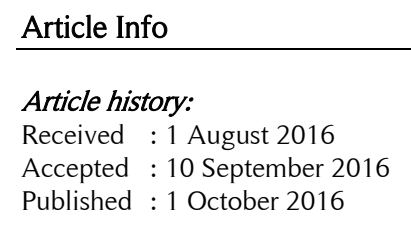

Keywords:

Loan, return on asset, return on equity, commercial bank

\section{JEL Classification: \\ G21, C33, F65}

DOI:

10.20885/ejem.vol8.iss2.art3

\begin{abstract}
This study examines the effect of lending on Micro, Small and Medium Enterprises (MSMEs) on the profitability of commercial banks in Indonesia. The profitability is measured as Return-on-Assets (ROA) and Return-on-Equity (ROE). It covers the period of 2011 to 2014 using a panel data regression model. It finds that MSME loans have a positive impact on ROE. The internal factors that significantly influence the profitability of banks are MSME's NPL (non-performing loan), the operational efficiency ratio (OER) and loan-todeposit ratio (LDR), while external factors that significantly influence the profitability of banks are inflation, Gross Domestic Product (GDP) growth and the Bank Indonesia (BI) rate.

\section{Abstrak}

Penelitian ini menguji pengaruh pinjaman Usaha Mikro, Kecil dan Menengah (UMKM) terhadap profitabilitas bank komersial di Indonesia. Profitabilitas tersebut diukur dengan Return-on-Assets (ROA) dan Return-on-Equity (ROE). Analisis dilakukan atas data yang terentang dari 2011-2014 dengan menggunakan regresi data panel. Hasil penelitian menyarankan bahwa pinjaman UMKM memiliki dampak positif pada ROE. Faktor internal berpengaruh signifikan terhadap profitabilitas bank adalah UMKM NPL (non-performing Ioan), operational efficiency ratio (OER) dan loan to deposit ratio (LDR), sedangkan faktor eksternal yang berpengaruh signifikan terhadap profitabilitas bank adalah inflasi, pertumbuhan Produk Domestik Bruto (PDB) dan tingkat Bank Indonesia (BI).
\end{abstract}

\section{Introduction}

Micro, Small and Medium Enterprises (MSMEs) have contributed in expanding the job opportunities and have given vast economic services for the society, as well has been playing a significant role in equalizing and improving the society's income, encouraging the economic growth, and creating national stability. The data from Ministry of Cooperation and MSMEs in 2013 show that the MSMEs share in GDP have reached $57.56 \%$ GDP in 2013. The number of MSMEs in Indonesia up to 2013 is 57.89 million units which comprise $99.99 \%$ of the total business units in Indonesia, and the amount of workforce in the MSMEs sector is 114.14 million people or $96.99 \%$ from the total workforce in overall business sectors in Indonesia. The number of MSMEs in 2013 grows by $2.41 \%$ compared to the number of MSMEs in 2012 with the increase of workforce which is 6 million of workforce.

Although MSMEs have shown their roles in national economy, MSMEs still face various challenges, such as capital, human resources and marketing. In empowering MSMEs, the government has done various efforts to increase the capital access as well as other resources for MSMEs. The preference of the government for MSMEs is reflected, for example, in the enactment of Law No. 20 of 2008 dated July 4th 2008 about Micro, Small Medium Enterprises that regulates the growth of business climate, business development as well as funding and warranties. To support the government program, Bank Indonesia has issued Bank Indonesia Regulation No 14/22/PBI/2012 Dated December 21, 2012 about the Funding and Loan by General Bank and Technical Aids in Developing Micro, Small and Medium Enterprises (Bank Indonesia, 2012a).

In the light of this regulation, Bank Indonesia requires general banks to give loan or funding for MSMEs as much as $20 \%$ of the total loan or bank funding at the very least, in which the fulfilment is done gradually until 2018. Bank Indonesia also gives relaxation for general banks that can meet the above requirements such as risk based consideration asset calculation, general bank asset quality assessment, and maximum loan exception as well as special treatment on bank loan for particular areas in Indonesia that suffers from natural disaster. Through Bank Indonesia Regulation No.14/26/2012 about Business Activities and Office Network Based on Core Capital, Bank

\footnotetext{
* This paper is a part of Thesis from Management and Business Graduate Program, Institut Pertanian Bogor (Bogor Agriculture Institute).
} 
Indonesia also gives 3 types of incentives for banks such as the ease of office network opening that still get the office network licensing for the banks that have met the health level but do not have Core Capital allocation, gives additional license for the office opening for the banks that meet the health level requirement and sufficiency of core capital to open functional office and special unit to serve MSMEs clients, if the banks have given loan for MSMEs minimum $20 \%$ of the total loan portfolio or the lowest MSMEs with the lowest value of $10 \%$ of the loan portfolio (Bank Indonesia, 2012b).

The above efforts have not shown optimum results because based on the data from Bank Indonesia, it shows that the MSMEs loan distribution in several bank groups are still relatively low (18.28\% of the total loan) while the most general bank assets in Indonesia is in the form of loan, that reaches the value of $66.0 \%$ from the total asset. Based on the Indonesian Banking Statistics data for the last 4 years (from 2011 to 2014), loan composition of MSMEs on total loan shows a negative trend from $20.82 \%$ to be $18.28 \%$, while the total loan compared to total bank asset increases from $60.68 \%$ in 2011 to be $66.0 \%$, as shown in the following figure:

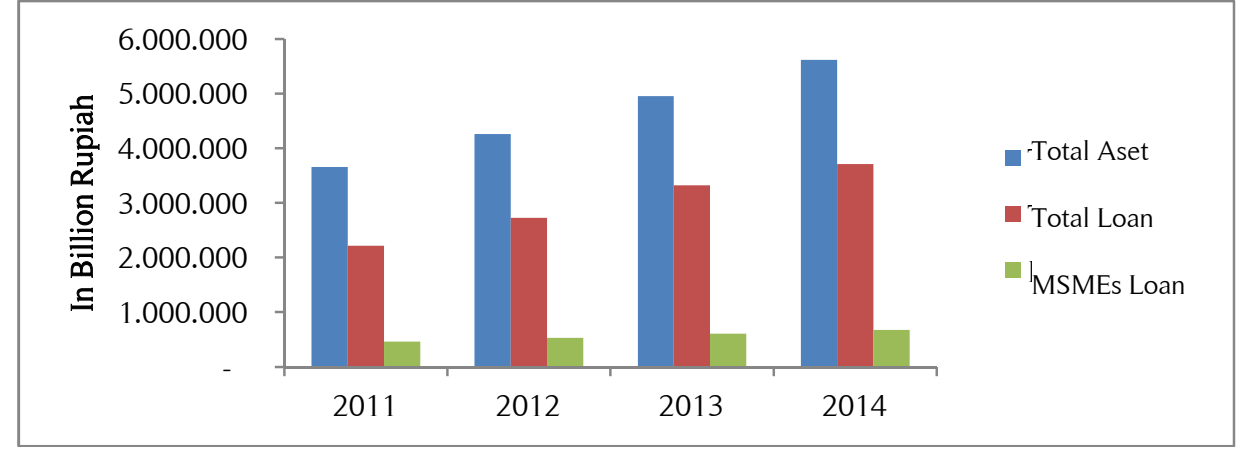

Source: Indonesian Banking Statistics-Bank Indonesia, 2014

Figure 1. Development of Assets, Total Loan and MSMEs loan

Although nominally the amount of MSMEs loan distribution in each bank group rises, but in terms of growth, it shows fluctuate trend and tends to decrease in 2014. It shows that there is bank hesitation to distribute loans for MSMEs sector although the government has given incentive and relaxation. From six conventional general bank groups in Indonesia, three of them suffer from growth decrease such is State Owned Banks, Non-foreign exchange Commercial banks, and Joint venture banks as shown in the following table.

Table 1. MSMEs Loan Growth (In Billion Rupiah)

\begin{tabular}{lrrrr}
\hline Bank Group & 2011 & 2012 & 2013 & 2014 \\
\hline State Owned Banks & 222,645 & 242,861 & 304,75 & 341,804 \\
Growth & & $9.08 \%$ & $25.48 \%$ & $12.16 \%$ \\
Foreign Exchange Commercial Banks & 176,925 & 205,731 & 217,529 & 230,998 \\
Growth & & $16.28 \%$ & $5.73 \%$ & $6.19 \%$ \\
Non-Foreign Exchange Commercial Banks & 17,309 & 23,26 & 27,572 & 30,367 \\
Growth & & $34.38 \%$ & $18.54 \%$ & $10.14 \%$ \\
Regional Development Banks (BPD) & 31,314 & 45,082 & 46,896 & 50,837 \\
Growth & & $43.97 \%$ & $4.02 \%$ & $8.40 \%$ \\
Joint Venture Bank & \multirow{2}{*}{6,651} & 8,75 & 11,378 & 13,467 \\
Growth & & $31.56 \%$ & $30.03 \%$ & $18.36 \%$ \\
Foreign Owned Bank & 332 & 712 & 697 & 4,247 \\
Growth & & $-78.55 \%$ & $-2.11 \%$ & $509.33 \%$ \\
TOTAL MSMEs & 458,164 & 526,396 & 608,822 & 671,72 \\
Growth & & $14.89 \%$ & $15.66 \%$ & $10.33 \%$ \\
\hline
\end{tabular}

Source: Banking Statistics Indonesia, 2014.

The result of the previous study conducted by Shahchera and Taheri (2013) on 17 general banks in Iran during 2000-2011 period shows that the distribution of loan to MSMEs has significant negative impact on the bank profitability in Iran. Funding in MSMEs is viewed to be riskier because they do not have sufficient collaterals so that the funding in MSMEs is limited. The increase on bank capital is viewed to be more influential on bank profitability growth (Return on Equity). Research conducted by Polodoo (2011) also shows that loan distribution on MSMEs is not negatively significant on the profitability of nine general banks in Mauritius during 2001 up to 2008 period. Banks are more focused on big companies because funding in MSMEs is seemed to be very risky 
with insufficient collateral. An important factor for the bank profitability is Credit Risk that uses ratio loan to deposit proxy.

Several studies on loan for MSMEs that have been conducted are studies on factors that influence the MSMEs loan, and studies about MSMEs loan influence on particular bank profitability. The result of the study shows that NPL, CAR, BOPO, ROA, DPK and inflation have significant on the increase of MSMEs loan, while the study on PT Bank Jabar Banten in 2002 to 2009 shows that the loan distribution for MSMEs fluctuate and have insignificant impact on bank operational income.

Based on the above data and the result of the previous studies, a further research is needed to prove whether loan distribution for MSMEs does not influence the increase of bank profitability in Indonesia, although interest rate for micro and retail loan is bigger than corporate loan that should influence the increase of bank profitability. Furthermore, a study is also needed to see if there are other factors that have more influence on bank profitability compared to loan distribution for MSMEs, internal and external factors as stated on the studies above.

\section{MSMEs loan definition}

According to Law No. 20 of 2008, MSMEs are productive economy businesses that stands independently, done by individuals or business entity which is not a subsidiary or a branch of the companies owned, acquired, or becoming direct or indirect part of medium scale or big-scale corporations that meet the following criteria. Micro Enterprises are productive business owned by individual and/or individual business entity that has net asset maximum of Rp50,000,000.00 not including land and building of the business site or has annual sales maximum Rp300,000,000.00. Small Enterprises are productive economy business that stands independently, done by individuals or business entities which are not branches of the companies owned, acquired, or becoming direct or indirect part of medium scale or big-scale corporation that has net asset more than Rp50,000,000.00 up to Rp500,000,000.00 not including the land and building of the business site or has annual sale more than Rp300,000,000.00 (three hundred million rupiah) up to Rp2,500,000,000.00. Medium Enterprises are economy product business that stands independently, done by individuals or business entity which is not a subsidiary or a branch of the companies owned, acquired, or becoming direct or indirect part of medium scale or big-scale corporation that has net asset more than Rp500,000,000.00 up to Rp10,000,000,000.00 not including land and building, or has annual sale more than Rp2,500,000,000.00 up to Rp50,000,000,000.00.

MSMEs loan is a loan given to the business owners that meet the Micro, Small, and Medium Enterprises criteria (Bank Indonesia, 2012a). Micro, Small and Medium Enterprises Loan refers to Law number 20 of 2008 about Micro, Small and Medium Enterprises. Through regulation No.14/22/PBI/2012, Bank Indonesia requires general banks to give loan for MSMEs minimum 20\% calculated based on the MSMEs loan ration towards total loan that the accomplishment is calculated each end of the year and implemented gradually since 2013 up to 2018. For the banks which are the branch offices from foreign owned bank and joint ventured bank, the loan or funding for non-oil and gas export is considered as MSMEs loan or funding.

MSMEs loan distribution can be done directly to MSMEs or through executing, channelling or syndication pattern. General banks that distribute loan for MSMEs will get relaxation in the form of Risk-based asset assessment, general bank asset quality assessment, loan distribution maximum exception for the banks in particular areas in Indonesia suffers from natural disasters. The calculation of MSMEs Risk based asset assessment is given the risk value decrease from $100 \%$ to be $75 \%$, and the MSMEs loan which is guaranteed by warranty institution or State-Owned Business which initially have the risk of $50 \%$ decreased to be $20 \%$. The loan quality assessment for MSMEs loan is based only on the punctuality of loan and/or interest payment without considering the business prospect and performance of the debtor.

Through BI regulation No.14/26/2012 about Business Activity and Office Networks based on core capital, there are 3 incentives for the banks that have distributed loan for MSMEs at least 20\% from the total loan portfolio or MSEs at least 10\% from the total loan portfolio in the form of easiness of office network opening in which it still get the license of opening office network for the banks that have met the health level requirements but do not have core capital allocation, get additional license of office opening for the banks that have met health level requirements and sufficiency of core capital, as well as getting exception of core capital allocation sufficiency for the opening of functional office or special unit that serve MSMEs customers.

\section{Profitability of Commercial Banking}

Profitability is the most appropriate indicator to assess the performance of a bank. The profitability assessment used is rate of return on equity (ROE) for general companies and return on asset (ROA) in banking industry.

Bank profitability is a function of internal and external factors. The internal factors are micro factors or bank-specific factors that determine profitability, while external factors are variables that do not have direct relation to bank management, but those factors indirectly give effect on economy and regulation that will influence the performance of financial institution. The external factors that need to be considered are inflation, interest rate, output cycle, as well as variables that present market characteristics. 
According to Demirgüç-Kunt and Huizinga (1999), financial sector is very sensitive and closely influenced by government policies as well as macro and micro economic condition in given country. Theoretically, there are several factors that can influence the performance of a bank, both internal and external ones. The internal factors are bank operational, risk management, and others. The external factors are monetary policies, fluctuation of exchange rate and inflation, volatility of interest rate, competition among banks or non-bank financial institutions and others.

The result of the study conducted by Guru, Staunton, and Shanmugam (2000), found out that internal factors that influence the bank profitability are loan to asset ratio, inclusion of the company subsidiary in the total asset, total cost towards total asset, and capital towards total asset. While external factors that influence the profitability are inflation and market interest rate. Loan-to-asset ratio has positive significant effect on profitability, while the research result indicates that general bank should be more focused on loan distribution rather than investment on securities and company subsidiaries.

\section{Research Method}

This research uses secondary data from Bank Indonesia in the form of Indonesian Banking Statistics (IBS) monthly report devised from 2011 up to 2014 for six groups of conventional general banks consists of State Owned Banks, Foreign Exchange Commercial Banks, Non-Foreign Exchange Commercial Banks, Regional Development Banks (BPD), Joint Venture and Foreign Owned Banks. The data analysis is conducted using EViews 8 software package with a panel data regression which is the combination between time dimension (2011-2014) and data dimension of six bank groups (cross section). The data of macroeconomic variables, namely inflation, Bi rate and exchange rate, are collected from Bank Indonesia website, which are monthly data. The GDP data are from Central Statistic Board (BPS) in quarterly period and processed pro-rated for each quarterly growth.

The model selection in this research is based on several journals, namely Polodos (2011) and Guru et al. (2000). The dependent variables are ROE and ROA, while MSMEs loan as well as bank internal and external factors are independent variables with the following equation

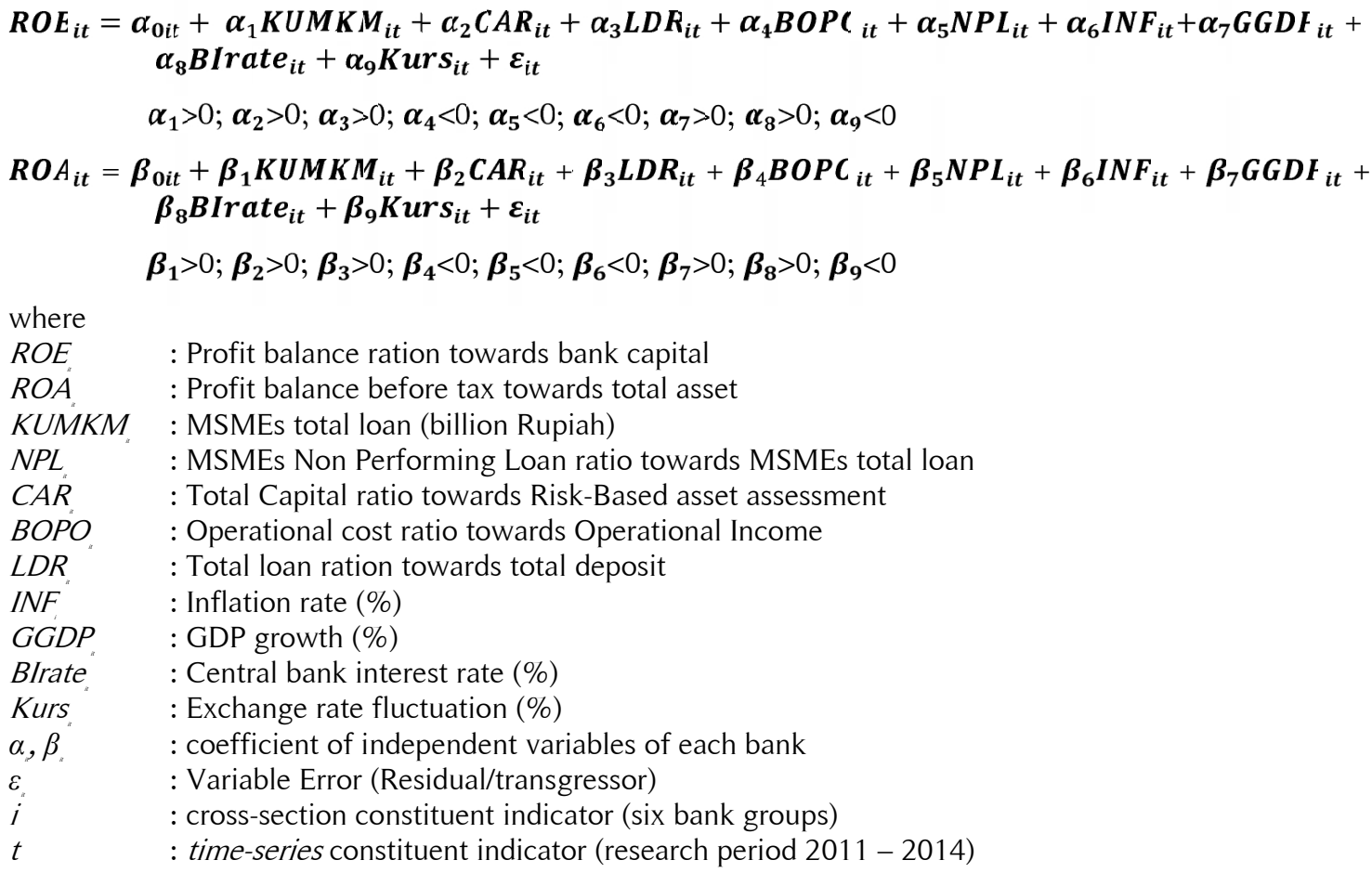

MSMEs loan is the loan distributed to business actors that meet the Micro, Small and Medium Enterprises criteria (Bank Indonesia, 2012a). The criteria of MSMEs are based on Law no 20 of 2008 about micro, small and medium enterprises. For the banks that are the subsidiaries of joint venture and foreign owned banks, the loan o funding to non-oil and gas export can be calculated as loan or funding for MSMEs. MSMEs loan distribution can be done directly to Micro, Small and Medium Enterprises or through executing, channelling or syndication cooperation pattern with Public Loan Bank or other non-bank financial institutions. In this research, the data used is the loan distribution directly by general banks for MSMEs (not including loan through Public Loan Bank cooperation) in billion rupiah. 
MSMEs NPL is the ratio of MSMEs non-performing loan towards the MSMEs total loan. Based on Bank Indonesia Regulation No.14/15/PBI/2012 about the General Bank asset quality assessment, it has been stated that the loan quality is divided into 5 types, such as Pass (P), Special Mention(SM), Substandard (S), Doubtful (D) and Loss (L). The enactment of these loans quality is done by analysing the factors from business prospects, financial performance and the capability to pay the debtor. A loan is said to be non-performing is it has the quality of S, D and L. Bigger NPL ratio indicates bigger amount of NPL towards the bank total loan. Bigger amount of NPL indicates bigger risk faced by the bank. In anticipating the potential loss that might arise from loan distribution, bank must form Reserved Value Depreciation Loss (RVDL) according to the existing accounting standard. RVDL is a reserved value which is formed if the financial asset booked value after the depreciation is less than the initial value. The forming of reserved value depreciation loss will be noted as operational costs beside interests. A high NPL will increases cost, therefore will have the potential to make the bank loss. The higher this ratio, the worse the bank loan quality that create the higher non-performing loan, therefore bank must bear the loss in their operational activities so that it will influence the profit decrease (ROA) gained by the bank.

MSMESNPL $=\frac{\text { MSMESNPL Loan }}{\text { Total MSME } \cdot \text { Loan }}$

Capital Adequacy Ratio (CAR) has been regulated by Bank Indonesia. Bank CAR component is the total capital towards Risk Based Asset assessment (RBAA). The capital banks that headquarter in Indonesia consist of core capital (Tier 1) and complementary capital (Tier 2). The form of core capital such as the capital submitted and spared additional capital, while core capital for branch office from the bank that has headquarter outside Indonesia, mostly in the form of business fund from Central Headquarter.

Meanwhile, the complementary capital is in the form of loan instruments that have capital characteristics, and is subordination as well as the highest amount is $100 \%$ from the core capital. RBAA used in core calculation minimum consists of RBAA for loan risk, RBAA for operational risk and RBAA for market risk. The higher the Car, the stronger is the bank's capability to bear the risks from each risky loan or productive assets. If the value of CAR is high (according to Bank Indonesia Regulation which is 8\%) it means that the bank can pay the operational costs for that bank, and this beneficial condition will give a quite big contribution on said bank profitability (ROA).

$\mathrm{CAR}=\frac{\text { Capital } \text { (core+complementary) }}{\mathrm{RBA} t(\text { Loan risk+Market Risk+Operational Risk) }}$

Operational cost towards operational income (BOPO), usually called as efficiency ratio used to calculate the bank management capability in controlling operational costs towards operational income. The smaller this ratio, the more efficient the operational cost paid by the bank. Operational cost consists of interest cost and operational costs aside from interests that consist of promotion cost, employee costs, and other operational costs. Operational income is the main income of the bank which is the interest gained from the funding in the form of loan or securities, as well as operational incomes aside from interests such as commission and provision/fee from the sale of financial asset and other operational incomes. Bank's main activities are their act as intermediaries, namely collecting and distributing society's fund. Therefore, the operational costs and income of the bank is dominated by interest costs and interest income. This BOPO ratio is to assess the capability of operational income in covering operation cost. Every increase of operational cost will have an impact on the decrease of profit before tax that subsequently causes the profit or profitability (ROA) of that bank. The equation used is:

$\mathrm{BOPO}=\frac{\text { Total operational cost }}{\text { Total Operational Income }}$

Loan-to-Deposit Ratio (LDR), according to Bank Indonesia, it is the loan ratio given to the third party in Rupiah and foreign exchange, not including loan to other banks, towards the third party including giro, savings and deposit in the form of Rupiah and foreign exchange, not including fund between banks. LDR ratio used to assess the bank capability to pay its debts and pay back their depositors, as well as the capability to fulfil the loan proposal. Or in the other words, how far is the loan distribution for customers, loan can balance the bank liability to immediately fulfil their depositors' need to withdraw their money that has been used by the bank to give loan, if bank cannot distribute the loan while the fund collected is in the high amount, the bank will suffer from loss, therefore, the higher the LDR, the company's profit is higher (with the assumption that the bank can distribute loans effectively, so that the amount of NPL is small). The equation used in this research is as follow:

LDR $=\frac{\text { Loan for third party }}{\text { Third Party's Fund }}$

Inflation is simply defined as the increase of the general prices and continuously. Inflation can also be defined by the rising of the goods and service prices in general in which the goods and services are the society's prime needs or the decrease of the exchange rate of a country's money. The indicator that mostly used to measure the inflation rate is Customer Price Index (CPI). The changes of CPI along the time show the movement of goods and services price consumed by the society. Since January 2014, CPI is based on the consumption pattern on the 
living cost survey in 82 cities in 2012. An inflation which is too high decrease economic growth, because society's purchase capability will drastically decreased, that causes the society to lower their consumption and purchase.

Gross Domestic Product (GDP) is the total amount of product in the form of goods and services produced by production units in a domestic area of a country for a year. In this GDP calculation, including the goods and services produced by foreign companies/individuals operating in said country. The goods produced including capital goods that have not been calculated the depreciation, because the total gained from GDP is gross. In this research, GDP data is in the form of quarter, therefore, an interpolation technique used to change the quarter data to be monthly data. Interpolation is a method to seek the value between several points of the known data. GDP is one of the macro economy indicators that mostly used as a measurement of total economic activities of an economy. Jiang, Tang, Law, and Sze (2003) research concludes that the decrease of real GDP growth gives negative impact on banking profitability in Hong Kong, and according to Demirgüç-Kunt and Huizinga (1999), the per capita GDP has no significant impact on realized net interest margins, while this variable enters with a positive coefficient in the profitability equation.

BI Rate is the interest rate policy that reflects a stance on monetary policy enacted by Bank Indonesia and announced to public. BI rate is announced by Bank Indonesia's Board of governors in monthly Board of Governors Meeting and implemented in monetary operation done by Bank Indonesia through liquidity management in monetary market to reach the monetary policy operational goals. Monetary policy operational goals are reflected on the development of interest rate of Monetary Market among Banks Overnight (PUAB O/N). The movement of this PUAB interest rate will be followed by the development of deposit interest rate, and in turn the bank loan interest rate. The interest rate (BI rate) becomes one of factors for banks to determine the interest rate offered to society. Interest rate influences the society's desire and interest to put their fund in that bank through the products offered. The effect of this for that bank is the higher the amount of fund put by the society, will increase the bank's capability in distributing the fund in the form of loans, in which from that loan the bank gains profit. Therefore, the more loans distributed, influences the income of the bank. Meanwhile, according to Gizycki (2001), the rise of interest rate is predicted to increase non-performing loan, therefore the increase of interest rate means the decrease of bank profitability. It is because the influence of interest rate in creating the decrease of loan quality is bigger than the bank's capacity in gaining profit.

Exchange rate has an important role in reaching monetary stability and in supporting economic activities. Rupiah exchange rate to USD shows how much rupiah needed to be exchanged to one USD. A stable exchange rate is needed to create a supporting climate for the improvement of business activities. With the implementation of free floating exchange rate system since August 14, 1997, the price of rupiah is determined by the market, therefore the application of exchange rate system reflects the balance of offers and demands. Foreign exchange rate becomes one of the banking profitability factors because in their activities, bank gives foreign exchange sales and purchase service. In normal situation, selling foreign exchange is basically very profitable because the transaction creates profit in the form of exchange difference. It is because foreign exchange actors always offer twice the exchange rate. In this transaction activity, foreign exchange rates become bank's concern because it can influence bank's profitability. With exchange rate fluctuation, bank can gain profit in the form of fee and rate difference.

ROA (Return on Asset) is profitability ratio that shows the ratio of profit (before tax) and total asset of the bank. This ratio shows the efficiency rate of the asset management done by the bank. According to Ongore and Kusa (2013), ROA measures the bank management's capability in gaining income by using their company's assets. The higher ROA shows that the company is more efficient in using their resources.

$\mathrm{ROA}=\frac{\text { Profit Before Tax }}{\text { Average Total Assets }}$

ROE (Return on Equity) is the ratio that shows bank's capability to use profit excess to increase the capital. The higher this ratio, the better that bank's capability in increasing the capital from profit balance.

$\mathrm{ROE}=\frac{\text { Profit Balance }}{\text { Average Core Capital }}$

\section{Result and Discussion}

Descriptive analysis result towards six groups of general conventional banks in Indonesia for the last four years in complete form can be seen in the table 2. The average loan distribution in MSMEs sector is Rp87.589 billion wth the lowest distribution by foreign owned bank which Rp318 billion and the higest by state-owned bank which is Rp341.804 billion. It shows that there is a very big gap between MSMEs loan distribution by state owned bank and foreign owned bank. MSMEs loan distribution in State owned bank is higher than foreign owned bank. It indicates that state owned banks have the wider network than foreign owned bank. State owned bank are banks that are appointed by the government to distribute loan to MSMEs in the form of Public Business Loan (KUR) with the collateral facility from the government through PT Askrindo and Perum Jamkrindo. 
The average MSMEs NPL is $4.02 \%$ with the lowest and the highest MSMEs NPL each $0.05 \%$ and $19.34 \%$ respectively in foreign owned banks. The highest NPL is reached in 2012, while the lowest NPL is in the end of 2014. The increase of the highest NPL happened when foreign owned bank suffer the MSMEs loan decrease from Rp3,320 billion in 2011 to be Rp712 billion in 2012. Meanwhile, the ratio of MSMEs NPL become the lowest after foreign owned bank increase their MSMEs distribution from Rp697 billion in 2013 to be Rp4,247 billion in 2014. It shows that the decrease of MSMEs NPL beside due to the increase of better MSMEs loan amount, it also because the foreign owned banks also have done the effort to overcome the problematic loan problems, reflected from the decrease of the amount of non-performing loan from 2011 to 2014.

Table 2. Descriptive Analysis Result

\begin{tabular}{lccccc}
\hline & Mean & Median & Max & Min & Std Deviation \\
\hline MSMEs *) & $87,589.44$ & $30,356.50$ & $341,804.00$ & $3,181,000$ & $102,253.60$ \\
MSMEs NPL & 0.040165 & 0.033535 & 0.193402 & 0.00051 & 0.02675 \\
CAR & 0.206638 & 0.188063 & 0.448125 & 0.140967 & 0.060264 \\
BOPO & 0.800497 & 0.79284 & $1,738,950$ & 0.661615 & 0.084264 \\
LDR & 0.919468 & 0.857673 & $1,489,338$ & 0.614931 & 0.183762 \\
INFL & 0.057608 & 0.0539 & 0.0879 & 0.0356 & 0.015951 \\
GDP & 0.05925 & 0.060835 & 0.065 & 0.049 & 0.005507 \\
BI Rate & 0.065938 & 0.0675 & 0.0775 & 0.0575 & 0.007454 \\
Exchange rate & 0.006556 & 0.003055 & 0.069879 & 0.040856 & 0.017468 \\
ROA & 0.029838 & 0.030268 & 0.056979 & 0.003602 & 0.006296 \\
ROE & 0.389186 & 0.438719 & 0.644754 & 0.088833 & 0.144594 \\
\hline
\end{tabular}

*) In Billion rupiah

For other internal factors such as CAR, BOPO, and LDR, can be stated that the Capital Adequacy Ratio (CAR) in average is $20.66 \%$ with the lowest ratio is $14.10 \%$ in Regional Development Bank (BPD) and the highest ratio is $44.81 \%$ in foreign owned banks. It shows that foreign owned bank have stronger capital in supporting the business expansion and absorbing the potential loss caused compared to BPD. The high amount of foreign owned banks' capital is because there is a requirement for foreign owned bank to form Capital Equivalency Maintained Assets (CEMA) minimum is $8 \%$ of the total bank liability each month and minimum one trillion rupiah. CEMA is the branch office business fund allocation for the bank that have the office in foreign country that must be placed in the financial asset in the particular amount and requirements according to BI regulation No.15/12/PBI/2013 about Requirements of General Bank Minimum Capital Reserve. The financial asset that can be considered as CEMA is securities issued by government, other banks that have legal entity in Indonesia that have investment rank and legal entity corporation securities in Indonesia with minimum A+ rank or equal to 0 percent risk.

The average BOPO ratio is $80.05 \%$ with the lowest and highest ratios are in state-owned-bank, $66.16 \%$ in 2013 and $173.89 \%$ in the early 2011, respectively. The BOPO benchmark, according to Bank Indonesia for business group general bank (BUKU I), is maximum 85\%; according to BUKU II are $78 \%$ - 80\%; according to BUKU III are $70-75 \%$, and and according to BUKU IV are $65 \%-60 \%$. These show that in the early 2011 , state owned bank is not really efficient in managing their business compared to other bank groups. This inefficiency can be caused by the high operational cost for interest rate, promotion cost, and presents to attract customers' fund that mostly in the form of deposit which is expensive fund and other costs. BOPO ratio is also going to be used as Bank Indonesia's consideration in approving the number of office network that is planned to be opened by the bank.

The average LDR ratio is $91.95 \%$ with the lowest ratio is $61.49 \%$ in BPD and the highest ratio of $148.93 \%$ in foreign owned banks. It is because the business fund from the headquarter office in the form of foreign loan or deposit needed for bank operational especially in loan distribution, not considered as third party's fund (DPK). The higher the market competition from foreign owned bank in getting third party's fund, the higher the funding given by the headquarter are. This characteristic makes foreign owned bank has the highest LDR compared to other bank groups, but the liquidity risk of the foreign owned bank is relatively low because there is a support from its headquarter in the form of loan or capital (Banking Industry Profile Report, 2015). The lower and higher threshold for LDR is enacted by Bank Indonesia which is $78 \%$ for the lower threshold and $92 \%$ for the higher threshold which is known as LDR target. If smaller than LDR target, bank will be punished by disincentive related to the Minimum Required Giro (MRG) formation in Bank Indonesia.

The external factors that are also analysed are inflation, GDP, BI rate and exchange rate fluctuation. Inflation since 2011 to 2014 in average is $5.76 \%$ with standard deviation of $1.59 \%$, it reflects that inflation in Indonesia is still relatively under control with standard deviation value of $1.59 \%$. Economic growth measured by GDP for the last 4 years in average is $5.92 \%$ with standard deviation of $0.55 \%$. It reflects the general growth of GDP in Indonesia during research period that has good value, because the average value is positive and as low 
standard deviation value. Average BI rate during research period is $6.59 \%$ with the standard deviation of $0.74 \%$ that shows the value of reference interest rate relatively good because it has low standard deviation, while the IDR exchange rate towards USD during research period in average is $0.66 \%$ with standard deviation of $1.75 \%$ that shows the change of exchange rate of IDR towards USD that fluctuates with high standard deviation.

Bank profitability that uses ROA and ROE proxy, it can be said that the average ROA is $2.98 \%$ with the lowest value of $0.36 \%$ in state owned banks and the highest of $5.70 \%$ in foreign owned banks. It indicates that foreign owned bank is more efficient in managing the assets to produce profit compared to state owned bank. Average ROE ratio is $38.92 \%$ with the lowest ratio of $8.88 \%$ to BPD and the highest ratio of $64.48 \%$ in state owned banks. It shows that state owned banks are more profitable for investors and shareholders compared to BPD.

According to the Bank Indonesia regulation about risk management, banks are required to minimize the potential of events that can cause the bank to loss, by identifying, supervising, and risk controlling that comes from banking business activities. Risk identification is done by analysing the risk in the bank and bank activities. Risk measurement is done by regular evaluation on assumption compliance, data source and procedures used to measure the risks. Risk supervising is done by evaluating the risk exposure such as performing stress test using macro economy assumption in the worse-case scenario. Risk control is done by managing the particular risks that can harm the bank business continuation. With a good risk management, it is expected that the external factors can be minimized the influence on the continuity of bank business.

Before conducting regression analysis, a classic assumption test is done to the data first, that consists of normality, multicolinearity, heteroskedascity, and autocorrelation tests. Based on the empiric experience of several statistic experts, with the total data more than $30(n>30)$ it can be assumed that the data has been normally distributed, while the multicolinearity test result shows that there is no independent variable couple that have the correlation coefficient of more than 0.8 or less than -0.8 as shown in the following table.

Table 3. Multicollinearity Test

\begin{tabular}{|c|c|c|c|c|c|c|c|c|c|}
\hline & MSMEs & NPL & BOPO & CAR & LDR & INFL & GDP & BI Rate & $\begin{array}{c}\text { Exchange } \\
\text { rate }\end{array}$ \\
\hline MSMEs & 1.0000 & & & & & & & & \\
\hline NPL & -0.0609 & 1.0000 & & & & & & & \\
\hline BOPO & -0.2181 & -0.1089 & 1.0000 & & & & & & \\
\hline CAR & -0.7443 & -0.2095 & 0.1815 & 1.0000 & & & & & \\
\hline LDR & -0.6179 & -0.4013 & 0.1270 & 0.6940 & 1.0000 & & & & \\
\hline INFL & 0.0298 & -0.1526 & -0.0353 & 0.1079 & 0.1853 & 1.0000 & & & \\
\hline GDP & -0.1038 & 0.1323 & 0.2249 & -0.2285 & -0.3611 & -0.4268 & 1.0000 & & \\
\hline BI Rate & 0.0837 & -0.1263 & 0.0509 & 0.1530 & 0.2658 & 0.6173 & -0.6974 & 1.0000 & \\
\hline Exchange rate & 0.0115 & -0.0598 & -0.1356 & -0.0009 & 0.0826 & 0.2580 & -0.1230 & 0.1116 & 1.0000 \\
\hline
\end{tabular}

The result of multicolinearity test for ROA and ROEshows the Durbin Watson value of 1.1933 and 0.5368 (outside the range $1.7-2.3$ ), and the heteroskedascity test using Glesjer test by regressing all independent variables with residual absolute value, there is independent variable that influence significantly on residual model. To repair this autocorrelation and heteroskedascity deviation, the model is modified using Cross-Section Weights (PCSE) standard error \& covariance (d.f. corrected) model.

To ensure that the data is stationary, therefore, a stationary test is done as shown in the following table.

Table 4. Stationarity Test

\begin{tabular}{lcc}
\hline & Statistic & Prob** \\
\hline ROA & -2.79232 & 0.0026 \\
ROE & -2.18681 & 0.0144 \\
MSMEs & -4.87883 & 0.0000 \\
MSMEs NPL & -2.07769 & 0.0189 \\
CAR & -2.37080 & 0.0089 \\
BOPO & -2.33831 & 0.0097 \\
LDR & -2.26660 & 0.0117 \\
INFL & -2.50099 & 0.0062 \\
GDP & -5.58739 & 0.0000 \\
BI Rate & -1.80253 & 0.0357 \\
Exchange rate & -9.06180 & 0.0000 \\
\hline
\end{tabular}


The above table shows that, with the confidence level of $95 \%$ of all independent variable and dependent variable that do not have unit root (stationary data).

In panel data analysis, there are three types of model, namely Pooled Least Square Model (PLS), Fixed Effect Model (FEM), and Random Effect Model (REM). Chow test is done to compare PLS and FEM model. If the Cross Section F and Chi Square probability value is 0.0000 which is smaller than Alpha 0.05, therefore the right model to be used is Fixed Effect Model (FEM) and vice versa. Further, a Hausman Test is done by comparing FEM and REM models. If the probability value of Random Cross Section is bigger than Alpha 0,05, therefore the best model that can be used is Random Effect model and vice versa. Chow test and Hausman test result using E-Views 8 software package shows that the best model to analyse ROA and ROE is the Fixed Effect Model.

Partial test result ( $t$-test) on the model shows that there are three independent variables which are significant towards ROA such as MSMEs NPL, BOPO, and GDP, as well as six independent variables which are significant towards ROE which are MSMEs, BOPO, LDR, and all external factors except exchange rate with the t-test probability value $<0.05$. Simultaneous test result ( $F$-test) also shows simultaneously the independent variables influence the dependent variables with the probability value of F-test $<0.05$, as shown in Table 5.

Table 5. Regression Model Analysis Results

\begin{tabular}{lccc|rcr}
\hline \multirow{2}{*}{ Independent variables } & \multicolumn{5}{c}{ Dependent variables } \\
\cline { 2 - 7 } & \multicolumn{7}{c}{ ROA } & \multicolumn{1}{c}{ ROE } \\
\cline { 2 - 7 } & \multicolumn{1}{c}{ Coef. } & t-test & Prob. & \multicolumn{1}{c}{ Coef. } & t-test & Prob \\
\hline Ln MSMEs & 0.000748 & 0.2017 & 0.2704 & 0.015901 & 0.0059 & 0.0397 \\
MSMEs NPL & 0.047033 & 0.0007 & 0.0015 & 0.025075 & 0.8576 & 0.8804 \\
CAR & 0.005683 & 0.6221 & 0.6685 & -0.219794 & 0.1264 & 0.1456 \\
BOPO & -0.016133 & 0.0007 & 0.0000 & -0.147378 & 0.0000 & 0.0001 \\
LDR & 0.008107 & 0.0586 & 0.0853 & -0.357309 & 0.0000 & 0.0000 \\
INFL & 0.019413 & 0.2728 & 0.3257 & 0.799201 & 0.0005 & 0.0004 \\
GDP & 0.289801 & 0.0000 & 0.0003 & -9.538193 & 0.0000 & 0.0000 \\
BI Rate & -0.076985 & 0.0942 & 0.1565 & -3.401245 & 0.0000 & 0.0000 \\
Exchange rate & -0.012201 & 0.2364 & 0.3911 & -0.284402 & 0.0869 & 0.0791 \\
R-Squared & & 0.625764 & & & 0.908448 & \\
F-Statistik & & 32.60609 & & & 193.4938 & 0.00000 \\
Prob (F-Statistic) & & 0.00000 & & & & \\
\hline
\end{tabular}

The table above shows the determination coefficient $(R)$ for ROA and ROE each is 0.625764 and 0.908448 . It shows that with FEM model, the variables used in this research can explain $62.58 \%$ ROA variable variation ROA and $90.84 \%$ ROE variable variation, while the rest is $37.42 \%$ and $9.16 \%$ explained by other variables that are not covered in this research.

This result shows that loan in MSMEs and MSMEs NPL have significant impact on bank profitability. Other internal factors that are significant to profitability are BOPO and LDR, while the external factors that have significant impact on profitability are inflation, GDP, and BI rate. Loan for MSMEs, NPL and inflation have significant positive impact on profitability, while BOPO, LDR, GDP and BI rate have negative significant impact on bank profitability.

Loan distribution to MSMEs has significant positive impact on ROE. Every $1 \%$ increase of loan for MSMEs will influence the increase of $1.59 \%$ ROE, but not significantly positive to ROA. Interest income is the main income of the bank, especially interest revenue from loan because loan is the core business of bank. The bigger the loan amount, the bank interest revenue will increase as well. Considering the amount of loan for MSMEs is still relatively low compared to bank total asset, the increase of profit from loan for MSMEs do not have significant influence on total bank profit so that the increase of MSMEs loan is not significant towards banks' ROA. The addition of profit gained from MSMEs loan distribution will influence the increase of bank profit towards capital of the bank, especially the core capital that become the ROE calculation component, so the MSMEs loan increase become significant on bank ROE. The result of this research is in compliance with the research by Polodoo (2011) that shows the loan distribution for MSMEs is not significant on bank ROA in Mauritius, but not in compliance with the research result by Shahchera and Taheri (2013) that stated the MSMEs loan has negative significant impact on bank ROE in Iran. It shows that the funding on MSMEs in Indonesia is still have the prospect for banking industry to improve their performance as well as declining the assumption that the funding for MSMEs sector does not influence or decrease bank profitability. The decrease of loan growth in MSMEs sector and the low MSMEs loan towards total loan distribution of the banks indicate that banks are not yet focused on loan distribution for MSMEs and still prefer distributing loan for non MSMEs sector.

MSMEs NPL has a positive impact on ROA, each 1\% increase of MSMEs NPL will increase 4.7\% of bank's ROA. MSMEs NPL ratio is the total MSMEs non-performing loan (Substandard, Doubtful and Loss quali- 
ties) towards total MSMEs loan. The increase of NPL ratio can be caused by the increase of MSMEs nonperforming loan amount or because the decrease of MSMEs total loan.

To anticipate the potential loss caused by the uncollected problematic assets, bank must value depreciation loss reserve (VDLR) and allowance for uncollectible assets (AUS). The formation of VDLR will be noted as bank operational cost, while the difference between the calculation of VDLR and AUS will be noted as the bank capital deduction. Every increase in NPL will decrease the bank operation profit.

The research result that shows MSMEs NPL has a positive significant influence on ROA, indicating that with the increase of MSMEs NPL, bank limits their loan to MSMEs and increase the loan distribution for non MSMEs which is considered to have lower risk and give more profit for the bank. It is in compliance with the research done by Limpaphayom and Polwitoon (2004) which shows that NPL has significant positive influence on ROA.

BOPO is one of parameters used to measure bank efficiency. The higher the BOPO ratio, the bigger the operational cost spent by the bank compared to operational operational income gained by the bank, therefore it can be said that the bank is inefficient in running their business. With the higher operational cost compared to operational income, it will influence the bank's profit gain, that in turn will influence the decrease of bank's ROA and ROE. Research result shows that each decrease of BOPO of $1 \%$ influence the decrease of 1.61 of bank's ROA and $14.74 \%$ of bank's ROE. It is in compliance with the research conducted by Almazari (2014) that studies internal factors that affecting profitability of Saudi Arabia and Jordan banks with the period of 2005-2011.

LDR is one of many ratios used to measure the adequacy of liquidity and bank intermediation function. The component of LDR is the loan given for third party, not including the loan for other banks, for third party that includes giro, savings and deposit. The higher the ratio shows that intermediation is proceeding because the fund collected from the society is distributed entirely in the form of loan, but is not entirely good in terms of bank liquidity and if it exceeds the target LDR assigned by BI, therefore the bank will be disincentive GWM LDR. The research result shows that the LDR increase has negative significant influence for ROE. Each $1 \%$ of LDR increase will decrease $35.73 \%$ of the bank's ROE, because with the increase of the loan amount therefore the bank need more support or more capital to increase the loan or business expansion. This research result is in compliance with the research by Jonattan and Xu (2011) that suggest that LDR is negatively influences ROE.

Inflation can be defined as the rise of general prices and it happens continuously. The indicator that mostly used to measure inflation is Customer Price Index (CPI). The influence of inflation rate to bank profitability depends on the influence on bank expense and revenue. The inflation influence the profit and loss on bank performance depends on whether an anticipation has been done for that inflation. If inflation has been anticipated before, and the interest rate has been adjusted so that the increase of income is faster than the increase of cost, and vice versa. This research result shows that inflation has positive significant effect on ROE, each $1 \%$ increase of inflation influence the increase of 79.92\% ROE. It is in compliance with the research by Guru et al (2000) that stated inflation has positive significant effect on ROE. It indicates that bank management has anticipated the inflation rate.

GDP is one of many parameters used to measure the economic growth. The higher economic growth will lead to the greater demand for loans. When the GDP growth slowing down especially during recession, the loan quality will cause the increase of default, therefore it decreases the profitability rate of the bank, and vice versa if the GDP rises, it indicates that the economy is growing, loan demand will increase and the loan quality will increase, that in turn will increase the bank profitability. The high profit will become an attraction for investors and shareholders to increase their investment in the form of capital investment. The result of the research shows that GDP has positive effect on the increase of ROA but has negative impact on ROE. This result is supported by Demirguc-Kunt and Huizinga (1999) that GDP growth has a positive effect on bank profitability.

$\mathrm{BI}$ rate is the interest rate policy enacted by Bank Indonesia to keep the stability of national economy. $\mathrm{BI}$ will increase $\mathrm{BI}$ rate if the future inflation is estimated to go beyond the target set, and otherwise, BI will decrease the $\mathrm{BI}$ rate if the future inflation is estimated to be below the target. In other worse-case scenario, $\mathrm{BI}$ rate increase is to control inflation. The increase of BI rate is followed by the increase of deposit interest rate and interest rate of banking loan. The increase of deposit interest rate will increase the bank funding cost, while the increase of loan interest rate will cause the decrease of loan demand by business world and can cause the increase of non-performing loan. IT also can cause the banks become more selective in investing or placing their customers' fund in BI rather than distributing it in the form of loan, because although the interest rate gained by the bank is lower than loan interest rate, but it is zero risk. The research result done shows that there is significant negative relation between BI rate and ROE. It is in compliance with the result of the research by DemirgucKunt and Huizinga (1999) that stated interest rate is related to bank profitability.

\section{Conclusion}

This paper shows that the loan distribution for MSMEs sector has significant impact on the profitability increase of the bank. It disproves the previous research by Shahchera andTaheri (2013) which stated that the loan distri- 
bution for MSMEs has negative significant impact on profitability, and the research done by Polodoo (2011), which stated that the loan distribution for MSMEs does not have significant negative impact on general bank profitability. Bank's BOPO and LDR are internal factors that have negative significant impacts on bank profitability, while external factors that have negative significant impact on bank's profitability are GDP and BI rate.

Policy implication of this research result is Bank Indonesia Policy No 14/22/PBI/2012 about Loan and Funding by General Bank and Technical Aid in Developing Micro, Small and Medium Enterprises that requires the banks to distribute loans for MSMEs minimum 20\%, as well as Bank Indonesia Regulation No 14/26/PBI/2012 about business activities and Office network based on bank core capital that gives easiness for banks to open new office network if the bank distributes loan or funding for MSMEs minimum 20\% or MSEs minimum 10\% from the total loan with the consideration of efficiency which is relevant to be enacted.

The suggestion that can be given from this research result for banking authority to increase their loan distribution for MSMEs sector is to make firmer policies for banks to distribute their loans for MSMEs and increase the efficiency by decreasing the BOPO ratio as well as keeping the liquidity by maintaining LDR ratio in the appointed limit. Easiness in opening office network in distributing MSMEs loan and other incentives is still needed by banks.

The suggestion for banking industry is to keep distributing loans for MSMEs by utilizing the easiness that have been given by the banking authority, especially the easiness to open office network and the limited core capital allocation, by maintaining liquidity rate (LDR) and efficiency (BOPO) therefore, banks' profitability remains good as well as anticipating the external factor changes.

\section{References}

Almazari, A. A. (2014). Impact of internal factors on bank profitability: Comparative study between Saudi Arabia and Jordan. Journal of Applied Finance \& Banking, 4(1), 125-140.

Bank Indonesia. (2012a). Bank Indonesia Regulation (PBI) No. 14/22/PBI/2012 dated December 21, 2012 concerning Lending or Financing by Banks and Technical Assistance in the Context of Development of Micro, Small and Medium Enterprises., Jakarta.

Bank Indonesia. (2012b). Bank Indonesia Regulation (PBI) No. 14/26/2012 dated December 27, 2012 concerning Operations and Office Network Based on Core Capital. Jakarta.

Gizycki M. 2001. The effect of macroeconomic conditions on bank's risk and profitability. Research Discussion Paper. 2001(06): 1-40.

Guru, B.K., Staunton, J., \& Shanmugam, B. (2000). Determinants of commercial bank profitability in Malaysia. Asian Academy of Management Journal, 5(2), 1-22.

Jiang, G., Tang, N., Law, E., \& Sze, A. (2003). The profitability of the banking sector in Hong Kong. Hong Kong Monetary Authority Quarterly Buletin, 9(36), 5-14.

Jonattan, T., \& Xu, X. (2011). The relationship between liquidity risk and performance: an empirical study of banks in Europe 2005-2010. (Unpublished Thesis]. Umea University, Sweden (SE).

Demirgüç-Kunt, A., \& Huizinga, H. (1999). Determinants of commercial bank interest margins and profitability: some international evidence. The World Bank Economic Review, 13(2), 379-408.

Ongore, V.O., \& Kusa, G.B. (2013). Determinants of financial performance of commercial banks in Kenya. International Journal of Economics and Financial Issues,3(1), 237-252.

Limpaphayom, P., \& Polwitoon, S. (2004). Bank relationship and firm performance: evidence from Thailand before the Asian financial crisis. Journal of Business Finance and Accounting, 31(9-10), 1577-1600.

Polodoo, V. (2011). The role of small and medium enterprises and bank profitability - A Mauritian perspective. Social Science Research Network Electronic Journal, 6(5), 1-46.

Shahchera, M., \& Taheri, M. (2013). Loan to SME and banking profitability, an Iranian perspective. International Economic Studies, 41(2), 1-12. 